\title{
PENERIMAAN DIRI ORANG DENGAN HIV/AIDS DI BALAI REHABILITASI SOSIAL ODH "BAHAGIA" MEDAN
}

\author{
Eldwin Sovian Mendrofa
}

Politeknik Kesejahteraan Sosial bandung, wianmendrofa3@gmail.com

Uke Hani Rasalwati

Politeknik Kesejahteraan Sosial Bandung, hanirasalwatiuke@gmail.com

Silvia Fatmah Nurusshobah

Politeknik Kesejahteraan Sosial Bandung, silvia.nurusshobah@yahoo.com

\begin{abstract}
This study contains a description of the Self-Acceptance of People Living With HIV/AIDS (PLWHA) at the Balai Rehabilitasi Sosial "Bahagia" Medan. This study aims to determine the self-acceptance of PLWHA which includes aspects of nonattachment, non-avoidance, nonjudgment, tolerance, and willingness in doing activities. The researcher used a descriptive method with a qualitative approach. Informants in this study were determined using a purposive sampling technique with the number of informants totaling 5 (five) people consisting of 3 (three) PLWHA, 1 (one) Social Assistance, and 1 (one) Social Worker. The data collection techniques used were in-depth interviews, observation, and documentation studies. The research results are outlined in every aspect. The nonattachment aspect showed that they were not tied to their past and accepted their current condition. The non-avoidance aspect shows that PLWHA still withdraw from their environment because of shame. The nonjudgment aspect shows that PLWHA assess the situation they experience as learning for them. The tolerance aspect shows that PLWHA can control their emotions. The willingness aspect shows that PLWHA are willing to carry out various activities. Based on those, the researcher proposes a program "Increasing SelfAcceptance of People with HIV/AIDS through Family Support" which aims to increase family awareness about the importance of support for PLWHA, dan increase awareness about the importance of interaction with their social environment.
\end{abstract}

\section{Key Word: self-Acceptance, people living with HIVIAIDS, family support}

\begin{abstract}
Abstrak
Penelitian ini berisi mengenai gambaran tentang Penerimaan Diri Orang dengan HIV/AIDS (ODHA) di Balai Rehabilitasi Sosial ODH "Bahagia" Medan. Penelitian ini bertujuan untuk mengetahui penerimaan diri ODHA meliputi aspek ketidakterikatan (nonattachment), tidak menghindar (nonavoidance), tidak menghakimi (nonjudgment), toleransi (tolerance), dan kesediaan (willingness) dalam melakukan aktivitas. Peneliti menggunakan metode deskriptif dengan pendekatan kualitatif. Informan dalam penelitian ditentukan secara purposive sampling berjumlah 5 (lima) orang terdiri dari 3 (tiga) orang dengan HIV/AIDS, 1 (satu) orang
\end{abstract}


Pendamping Sosial, dan 1 (satu) orang Pekerja Sosial. Teknik pengumpulan data wawancara mendalam, observasi dan studi dokumentasi. Hasil penelitian dari aspek ketidakterikatan menunjukkan bahwa ODHA tidak terikat dengan masa lalunya dan menerima kondisi yang dialaminya saat ini. Aspek tidak menghindar menunjukan bahwa ODHA masih menarik diri dengan lingkungan karena adanya rasa malu. Aspek tidak menghakimi menunjukkan bahwa ODHA menilai situasi yang dialami sebagai pembelajaran baginya. Aspek Toleransi menunjukkan bahwa ODHA dapat mengendalikan emosinya. Aspek kesediaan menunjukkan bahwa ODHA bersedia untuk melaksanakan berbagai kegiatan. Berdasarkan hal tersebut untuk meningkatkan penerimaan diri ODHA peneliti merekomendasikan program peningkatan penerimaan diri ODHA melalui dukungan keluarga yang bertujuan meningkatkan kesadaran keluarga tentang pentingnya dukungan kepada ODHA, dan meningkatkan kesadaran ODHA tentang pentingnya interaksi dengan lingkungan sosialnya.

Kata Kunci: Penerimaan Diri, Orang dengan HIVIAIDS, dukungan keluarga 


\section{PENDAHULUAN}

Gaya hidup modern yang berkembang di Indonesia telah membawa orang-orang menuju kehidupan yang konsumtif dan memasuki pergaulan bebas. Dalam pergaulan bebas orang mengekspresi-kannya dengan bebas pula, salah satunya perilaku seks bebas yang semula di anggap tabu dan tidak bermoral, sekarang dianggap biasa dan wajar. Hal ini ditunjukkan dengan semakin meningkatnya perilaku seks bebas dari tahun ke tahun. Salah satu permasalahan yang muncul sebagai akibat dari perilaku seks bebas adalah terkait dengan penularan virus HIV. Dari tahun 1987 sampai dengan 2020 terdapat 419.551 Kasus HIV dengan penyumbang terbesar adalah perilaku seks bebas dengan presentase 30,8\% (Kemenkes RI Tahun 2020).

Virus

HIV

(Human

Immunodeficiency Virus) adalah sebuah virus yang menyerang sistem kekebalan tubuh manusia (terutama limfosit CD4) sehingga menyebabkan AIDS. AIDS (Acquired Immune Deficiency Syndrome) adalah suatu kumpulan gejala penyakit akibat kerusakan sistem kekebalan tubuh yang disebabkan oleh Human Immunodeficiency Virus (HIV). Penyakit ini telah menjadi isu global sebab dalam waktu yang relatif singkat terjadi peningkatan jumlah penderita penyakit tersebut di seluruh dunia. Kasus AIDS pertama kali dilaporkan oleh Gottleib dan sejawatnya di Los Angeles tanggal 5 Juni 1981. Ketika itu Centers for Disease Control and Prevention (CDC) Amerika Serikat mencatat adanya kasus ini pada lima laki-laki homoseksual di Los Angeles. UNAIDS dan WHO memperkirakan bahwa AIDS telah membunuh lebih dari 25 juta orang sejak pertama kali diakui tahun 1981. Hingga tahun 2020 diperkirakan ada 38 juta orang di seluruh dunia yang positif terinfeksi HIV (UNAIDS, 2020).

Kasus HIV di Indonesia pertama kali ditemukan di Bali pada tahun 1987, dan setiap tahun mengalami peningkatan secara signifikan. Perkembangan kasus HIV sampai dengan tahun 2020 tercatat sebanyak 640.443 kasus, dengan distribusi kasus yaitu terbanyak pada tenaga non profesional (karyawan) sebesar $26,4 \%$, ibu rumah tangga sebesar $15.5 \%$ dan wiraswasta $12,6 \%$. Lima kasus HIV-AIDS paling banyak tersebar di Provinsi Jawa Timur, DKI Jakarta, Provinsi Papua, Provinsi Jawa Barat, dan Provinsi Jawa Tengah (Kemenkes RI, Tahun 2020).

Kasus HIV-AIDS pada mulanya berasal dari kelompok homoseksual, kemudian berlanjut kepada kelompok lainnya seperti Pengguna NAPZA jarum suntik (PENASUN), dan kelompok heteroseksual. Sekarang ini penularan telah menyebar ke semua orang dan tidak hanya pada populasi berperilaku risiko tinggi. Data yang ada menunjukkan bahwa HIV-AIDS telah menginfeksi ibu rumah tangga, bahkan pada anak-anak atau bayi yang dikandung atau tertular dari ibu pengidap HIV.

Orang Dengan HIV/AIDS (ODHA) merupakan salah satu Pemerlu Pelayanan Kesejahteraan Sosial (PPKS), karena mengalami hambatan, kesulitan, atau 
gangguan, sehingga tidak dapat melaksanakan fungsi sosialnya.

Permasalahan yang dialami oleh ODHA meliputi permasalahan fisik, psikis, dan sosial ekonomi. Secara fisik, ODHA mudah terinfeksi berbagai penyakit. Permasalahan psikis, seperti tertekan, stres, dan tidak punya semangat hidup lebih disebabkan karena gonjangan jiwa atas vonis bahwa dirinya mengidap virus HIV/AIDS. Permasalahan sosial yang dihadapi ODHA karena adanya stigma negatif yang berkembang di masyarakat menyebabkan ODHA dikucilkan, bahkan diasingkan oleh masyarakat dan keluarganya. Hal tersebut membuat ODHA membutuhkan pelayanan kesehatan secara komprehensif, pelayanan-pelayanan sosial, dan pelayanan advokasi untuk menjamin hak-hak sipil maupun hak azasi manusia, serta pelayanan pendidikan menyeluruh (Nurhayati 2018).

Terdapat beberapa faktor yang mempengaruhi seseorang dalam penerimaan diri menurut Hurlock (2007) yaitu sebagai berikut:

a. Pemahaman Diri. Pemahaman diri adalah suatu persepsi atas diri sendiri yang ditandai oleh keaslian bukan kepura-puraan, realistis bukan khayalan, kebenaran bukan kebohongan, keterus-terangan bukan berbelit-belit.

b. Harapan yang realistis. Ketika pengharapan seseorang terhadap sukses yang akan dicapai merupakan pengharapan yang realistis, kesempatan untuk mencapai sukses tersebut akan muncul, sehingga akan terbentuk kepuasan diri sendiri yang pada akhirnya membentuk sikap penerimaan terhadap diri sendiri.

c. Tidak hadirnya hambatan-hambatan dari lingkungan. Ketidakmampuan untuk mencapai tujuan yang realistis dapat disebabkan oleh ketidakmampuan individu untuk mengontrol adanya hambatan-hambatan dari lingkungan, misalnya: diskriminasi, ras, gender, dan kepercayaan.

d. Tidak adanya tekanan emosi yang berat. Tekanan yang berat dan terus menerus seperti yang terjadi di lingkungan kerja atau rumah, dimana kondisi sedang tidak baik, dapat mengakibatkan gangguan yang berat, sehingga tingkah laku orang tersebut dinilai menyimpang dan orang lain menjadi terlihat selalu mencela dan menolak orang tersebut.

e. Sukses yang sering terjadi. Kegagalan yang sering menimpa menjadikan seseorang menolak terhadap diri sendiri, sebaliknya kesuksesan yang sering terjadi menumbuhkan penerimaan terhadap diri sendiri.

f. Konsep diri yang stabil. Konsep diri yang baik akan menghasilkan penerimaan diri yang baik namun sebaliknya bila konsep diri yang buruk secara alami akan menghasilkan penolakan terhadap diri sendiri.

Berdasarkan dari faktor-faktor diatas bahwasannya ada beberapa hal yang mempengaruhi penerimaan seseorang diamana kegagalan yang menimpanya bisa diterima dengan baik sehingga dapat membuat konsep diri menjadi lebih baik, 
tidak terdapatnya tekanan emosi yang berat, tidak menyalahkan orang lain atas apa yang terjadi dan dapat mengatasi hambatan dari lingkungan dan dapat menjalani kehidupan dengan segala kemampuannya.

Penerimaan diri memiliki peranan yang penting dalam diri individu. Self acceptance dapat membantu individu dalam berinteraksi dengan lingkunganya, meningkatkan kepercayaan diri, mengetahui dan menerima kekurangan dan kelebihan dalam dirinya dan mencoba menilai apa yang harus dilakukan individu tersebut.

Beberapa manfaat seseorang yang memiliki penerimaan diri menurut Jersild dalam Nurviana, (2006) yaitu:

a. Memilik penilaian realistis terhadap potensi-potensi yang dimilikinya.

b. Mereka juga menyadari kekurangan tanpa menyalahkan diri sendiri

c. Memiliki spontanitas dan tanggung jawab terhadap perilakunya.

d. Mereka menerima kualitas-kualitas kemanusiaan mereka tanpa menyalahkan diri mereka terhadap keadaan-keadaan di luar kendali mereka.

Hal terpenting ketika seseorang mampu menerima dirinya adalah ketika seseorang tersebut dapat menerima segala potensi yang ada pada dirinya, baik itu yang berkaitan dengan kelebihan yang dimilikinya juga yang berkaitan dengan kelemahan/ kekurangan yang ada pada dirinya maka orang tersebut akan dapat berinteraksi dengan baik dengan orang lain karena orang tersebut akan bersedia menerima kritik ataupun penolakan dari orang lain dengan sikap positif.

Salah satu lembaga pemerintah yang memberikan pelayanan rehabilitasi sosial bagi Orang Dengan HIV/AIDS adalah Balai Rehabilitasi Sosial ODH (BRSODH) "Bahagia" Medan. ODHA mendapatkan pelayanan rehabilitasi sosial untuk proses refungsionalisasi dan pengembangan diri sehingga mampu melaksanakan fungsi sosial secara wajar dalam kehidupan masyarakat. Mereka mendapatkan pelayanan rehabilitasi sosial bervariasi antara 2 Minggu, 2 Bulan atau 4 Bulan.

Keberfungsian sosial ODHA dapat dilihat dari berfungsinya aspek-aspek penerimaan diri. Penerimaan diri merupakan kemampuan seseorang secara penuh dan tanpa syarat dalam menerima dirinya sendiri. Berdasarkan pendapat Bernard bahwa penerimaan diri itu menerima diri secara penuh, sejalan dengan konsep penerimaan diri tanpa syarat tentu harus menerima karakteristik diri (Bernard 2013).

Penerimaan diri mencakup beberapa aspek yaitu (a) ketidakterikatan (nonattachment), yaitu menerima bahwa pengalaman yang telah berlalu, membiarkan pengalaman datang dan pergi lebih baik daripada upaya untuk mengendalikan atau mempertahankan pengalaman tersebut; (b) tidak menghindar (non-avoidance) yaitu menahan diri dari melarikan diri sia-sia ketika tidak ada ancaman; (c) tidak menghakimi (nonjudgment) yaitu penghentian secara sadar dari kategorisasi pengalaman sebagai baik atau buruk, benar atau salah, 
menggambarkan rangsangan daripada mengevaluasi rangsangan; (d) toleransi (tolerance) dapat tetap hadir bahkan ketika rangsangan membuat frustrasi atau tidak diinginkan; (e) kesediaan (willingness) menggunakan pilihan untuk memiliki pengalaman.

Rendahnya kepercayaan diri terhadap kemampuan diri sendiri dan selalu merasa malu dengan kondisi fisik yang dimiliki merupakan gambaran ciri seseorang belum memiliki penerimaan diri. Permasalahan internal maupun eksternal yang dialami oleh ODHA tentu akan dipengaruhi oleh tingkat penerimaan diri masing-masing individu. Jika penerimaan dirinya positif maka dirinya akan mampu mengatasi masalah internal berkaitan dengan kepercayaan diri terhadap kondisi fisik yang dialaminya begitupun masalah eksternal berkaitan dengan pola interaksinya selama di balai, namun jika penerimaan dirinya negatif, ODHA akan mengalami konflik berupa tekanan psikologis pada diri sendiri.

ODHA di BRSODH Bahagia Medan diketahui terkadang tidak memiliki keinginan untuk mengonsumsi obat rutin. Selain itu, ODHA juga lebih sering menyendiri. Beberapa ODHA sering menangis ketika memikirkan kondisi dan situasi kehidupannya saat ini yang dipandang buruk. Hal-hal tersebut disebabkan oleh pandangan negatif ODHA terhadap dirinya sendiri, yang mengindikasikan isu penerimaan diri.

Penelitian ini menjadi penting untuk diteliti, mengingat keunikan kondisi pandemi covid 19 yang menjadikannya sebagai faktor pembeda dari penelitianpenelitian sebelumnya. Selain itu, penelitian dengan topik penerimaan diri di BRSODH Bahagia Medan yang dilakukan oleh peneliti saat ini merupakan yang pertama di lokasi ini.

\section{METODE}

Metode penelitian yang digunakan adalah metode penelitian kualitatif. Metode penelitian kualitatif bertujuan untuk mengkaji teori yang dilakukan oleh peneliti.

Dalam penlitian kualitatif ini penulis ingin memperoleh makna mendalam dan penggambaran realitas mengenai "Penerimaan Diri Orang Dengan HIV/AIDS Di Balai Rehabilitasi Sosial ODH "Bahagia" Medan Provinsi Sumatera Utara”. Hasil penelitian bermakna yang sesuai dengan tujuan tersebutjuga memperhatikan teori, metodologi, dan desain penelitian kualitatif dalam pelaksanaan prosesnya maupun pengolaan hasilnya.

Sumber data primer adalah sumber data yang diperoleh secara langsung dari informan sebanyak 5 orang yaitu 3 orang dengan HIV/AIDS, 1 Orang Pekerja sosial dan 1 orang Pendamping Sosial ODHA di Balai Rehabilitas Sosial ODH "Bahagia" Medan di Provinsi Sumatera Utara yang menjadi informan.

Sumber data sekunder adalah data yang tertulis, dokumen, foto, literatur, penelitian terdahulu, atau buku yang berkaitan dengan masalah penelitian yaitu Penerimaan Diri Orang Dengan HIV/AIDS Di Balai Rehabilitasi Sosial 
ODH "Bahagia" Medan Provinsi Sumatera Utara. Data sekunder yang di peroleh berupa profil lembaga, Rekam asesmen ODHA, dokumentasi berupa foto-foto struktur lembaga, dan grafik jumlah HIV/AIDS di Balai BRSODH Bahagia Medan.

Peneliti menentukan informan dengan tujuan bahwa informan yang dipilih mampu memberikan informasi yang dibutuhkan oleh peneliti terkait penerimaan diri orang dengan HIV/AIDS. Peneliti memilih informan tersebut dengan tujuan bahwa informan yang dipilih mampu memberikan informasi yang dibutuhkan oleh peneliti terkait HASIL PENELITIAN

Informan dalam penelitian ini berjumlah 5 (lima) orang, yang terdiri atas orang dengan HIV/AIDS (ODHA) 3 penerimaan diri orang dengan HIV/AIDS. Teknik penentuan informan menggunakan teknik purposive sampling. "Teknik purposive sampling adalah teknik pengambilan sumber data dengan pertimbangan tertentu" Artinya peneliti memilih informan berdasarkan kebutuhan penelitian dengan mempertimbangkan berbagai hal informan utama adalah yang memenuhi kriteria, berjenis kelamin lakilaki, ODHA yang baru positif maksimal 2 Tahun sejak waktu penelitian, berusia 24 47 tahun, ODHA bertempat tinggal di balai, tidak menjalani pelayanan secara online, dapat bekerjasama dan bersedia memberikan informasi. orang, 1 orang Pendamping Sosial ODHA, dan 1 Orang Pekerja Sosial di BRSODH Bahagia Medan di Provinsi Sumatera Utara.

Tabel 1 Karakteristik Informan Penelitian

\begin{tabular}{|c|c|c|c|c|}
\hline Inisial & $\begin{array}{c}\text { Jenis } \\
\text { Kelamin }\end{array}$ & Usia & Pendidikan & Pekerjaan \\
\hline RA & L & 34 Tahun & SMA & Penjual Bakso \\
\hline ED & L & 24 Tahun & SMA & Konten Kreator \\
\hline SU & L & 47 Tahun & SMA & Penjual Parfum \\
\hline TI & P & 39 Tahun & SMA & $\begin{array}{c}\text { Pendamping Sosial } \\
\text { ODHA }\end{array}$ \\
\hline BL & P & 26 Tahun & D-IV & Pekerja Sosial Balai \\
\hline
\end{tabular}

Tabel diatas menunjukkan mengenai jumlah dan karakteristik informan dalam penelitian "Penerimaan Diri Orang Dengan HIV/AIDS Di Balai Informan $\boldsymbol{R A}$ Informan RA terinfeksi virus HIV pada Tahun 2019 karna
Rehabilitasi Sosial ODH "Bahagia" Medan Provinsi Sumatera Utara"

mengalami gejala HIV seperti demam tinggi, vertigo, diare, badan terasa lelah, 
mulut berjmur, alergi dan bitnik-bintik merah dikulit sehingga informan RA memutuskan untuk melakukan cek kesehatan di Rumah Sakit. Informan RA mengalami penuran HIV dari berhubungan seksual. Informan RA memiliki orientasi seksual yang menyukai sesama jenis. Informan RA bekerja sebagai penjual parfum yang pendapatannya kadang tidak menentu akibat danpak Covid-19. Ayah RA sudah meninggal dan dulunya bekerja sebagai pedagang sedangkan ibunya bekerja sebagai ibu rumah tangga dan informan RA adalah anak keempat dari enam bersaudara. Informan RA pun mengikuti kegiatan seperti bobershop dan juga kuliner.Informan ED Informan ED terinfeksi virus HIV pada Tahun awal tahun 2020 karna mengalami gejala HIV seperti mulut berjamur dan bitnik-bintik merah dikulit sehingga informan ED memutuskan untuk melakukan cek kesehatan di Rumah Sakit. Informan ED juga tidak mengetahui mengalami penularan HIV dari siapa akan tetapi informan ED memiliki orientasi seksual yang menyukai sesama jenis dan juga memiliki tato pada bagian tangan dan dada. Informan ED bekerja sebagai konten creator yang aktif bermain media sosial berupa Instagram dan Bigo Live. Ayah dan ibu masih ada akan tetapi sudah bercerai dan memiliki satu orang saudara. Informan ED pun mengikuti kegiatan seperti tata boga, MC, dan Badminton.Informan SU Informan SU terinfeksi virus HIV pada Tahun 2019 karna mengalami gejala HIV seperti demam tinggi, vertigo, diare, badan terasa lelah, mulut berjmur, alergi dan bitnik-bintik merah dikulit sehingga informan SU memutuskan untuk melakukan cek kesehatan di Rumah Sakit. Informan SU mengalami penuran HIV dari berhubungan seksual. Informan SU memiliki orientasi seksual yang menyukai sesama jenis. Informan SU bekerja sebagai penjual parfum yang pendapatannya kadang tidak menentu akibat danpak Covid-19. Ayah SU sudah meninggal dan dulunya bekerja sebagai pedagang sedangkan ibunya bekerja sebagai ibu rumah tangga dan informan SU adalah anak keempat dari enam bersaudara. Informan SU pun mengikuti kegiatan seperti bobershop dan juga kuliner.Informan TI Informan TI adalah seorang Pendamping Sosial ODHA di BRSODH Bahagia Medan, yang telah bekerja di balai pada tahun 2017 dan juga merupakan anggota Ikatan Perempuan Positif Indonesia dari Tahun 2012. Informan TI sudah berkeluarga dan memiliki suami dan satu orang anak tapi keduanya sudah meninggal dunia. Informan TI melaksanakan tugas sebagai pemberi edukasi, informasi, dukungan kepada ODHA yang memiliki masalah sosial, ekonomi dan sebagainya, bimbingan, konseling dan sebagai orang yang mengingatkan para ODHA untuk rutin minum obat selama dibalai. Informan TI tinggal bersama dengan ODHA di ruang asrama putri Informan $\boldsymbol{B L}$ Informan BL adalah seorang Pekerja Sosial di BRSODH Bahagia Medan yang telah bekerja selama 2 Tahun. Informan BL telah memiliki keluarga, yaitu satu orang suami dan satu orang anak. Informal BL memiliki jabatan 
sebagai Pekerja Sosial Ahli Pertama yang ditugaskan di bagian Rehabilitasi Sosial yang memiliki fungsi untuk melaksanakan Asesmen, membuat Rencana Intervensi,
Intervensi, Evaluasi, Terminasi dan berbagai tugas lainnya. kepada orang dengan HIV/AIDS

\section{Perasaan ketidakterikatan (nonattachment)}

Perasaan Ketidakterikatan yang dimaksud adalah tidak menyalahkan diri, menerima kondisi atau kejadian yang telah berlalu, motivasi dari lingkungan dan membiarkan pengalaman datang dan pergi lebih baik daripada upaya untuk mengendalikan atau mempertahankan pengalaman tersebut. Pernyataaan Informan RA menunjukan bahwa informan RA masih mengingat kerjadian yang menyebabkan dirinya menjadi ODHA, penyababnya adalah hubungan sesama jenis dan mencoba menerima kenyataan hidupnya dan harus melewati fase itu dan menerima bahwa HIV/AIDS adalah bagian dari dirinya, tidak menularkan lagi kepada orang lain dan sebagai pembelajaran baginya tanpa menyalahkan dirinya sendiri. informan ED juga menyampaikan hal yang sama.

Pernyataan Informan

SU

menggambarkan bahwa sekarang tidak menyalahkan dirinya ketika mengingat kejadian yang dialaminya karna lebih ingin berpikir positif dan selalu berfikiran bahwa dirinya sehat. Pernyataan informan TI menunjukan bahwasannya ODHA setelah berada di balai diberi penyadaran dukungan atau konseling dan informasi yang benar kepada ODHA maka ODHA di balai mulai bangkit untuk tidak menyalahkan dirinya, pernyataan yang sama juga di sampaikan Informan BL.
Pernyataan informan RA menunjukan adanya rasa kecewa, depresi dan pengen bunuh diri jika mengingat kejadian yang menyebabkan dirinya menjadi seorang ODHA tapi lama kelamaan RA mulai menerima dan menyadari perbuatannya sehingga mau melanjutkan kehidupan lagi. Pernyataan yang sama juga disampaikan oleh Informan ED menunjukan adanya rasa kecewa, dan ada niatan bunuh diri tapi sekarang semenjak di balai jika informan ED mengingat hal tersebut informan ED sudah meneriman dan menjadikan hal tersebut sebagai pelajaran baginya. Pernyataan dari informan SU meyebutkan pada adanya rasa sedih, kecewa dan setres, tapi sekarang SU lebih memilih untuk menerima karna telah mendapat edukasi dan obat sehingga rasa takut informan SU pun sekarang menghilang dan menjadikan hal tersebut sebagai pembelajaran dalam hidupnya.

Pernyataan Informan TI menyampaikan bahwasannya pada awalnya para ODHA di balai merasakan ada rasa takut, dan mau bunuh diri dan setelah didampingi dan ada seseorang yang mau mendengarkan cerita mereka, sehingga para ODHA menjadi semangat lagi untuk menjalani hidup. Pernyataan Informan BL menyampaikan 
bahwasannya adanya perasaan ODHA di balai merasakan kecewa, putus asa, menyesal dan mau bunuh diri dan setelah menjalani masa rehabilitasi mereka jadinya mempunya teman sebaya, para pekerja sosial yang mendengarkan cerita mereka sehingga para ODHA menjadi semangat lagi untuk menjalani hidup

Perasaaan ketidakterikatan (nonattachment) di gambarkan bahwasannya ODHA dalam hal ini informan RA, ED dan SU menyatakan bahwa tidak menyalahkan dirinya ketika mengingat kejadian yang dia alami dengan pernyataan seperti informan RA yang menjelaskan bahwa HIV/AIDS adalah bagian dari dirinya, informan ED lebih memilih untuk menjalani hidup dan SU berpikir positif dan selalu berfikiran bahwa dirinya sehat. Persamaan lainnya juga adalah bahwa ketiga informan ini mengalami gejala HIV/AIDS setalah melakukan hubungan seksual sesama jenis. Perbedaan pernyataaan yang disampaikan informan pada aspek perasaaan ketidakterikatan (nonattachment) dijelaksan pada jangka waktu ODHA bisa menerima diripun berbeda-beda. Informan RA menjelaskan bahwa dirinya membutuhkan waktu selama 1 (satu) Tahun untuk mau melanjutkan kehidupannya lagi. Informan ED butuh waktu 4 (empat) bulan untuk menerima dirinya sebagai orang dengan HIV/AIDS sedangkan informan SU butuh waktu 1 (satu) bulan untuk menerima dirinya sebagai orang dengan HIV/AIDS. ODHA bisa menerima diripun disebabkan oleh berbagai faktor seperti edukasi yang diberikan oleh pihak balai, support dari keluarga dan konseling yang diberikan kepada informan. Perbedaan lainnya terletak pada waktu dan tempat ODHA mengetahui dirinya menjadi orang dengan HIV/AIDS. Informan RA terkena HIV setelah adanya gejala demam dan penyempitan saraf wajah sehingga harus mengecek ke puskeesmas pada Tahun 2019. Informan ED Mengetahui bahwa dirinya terkena HIV setelah adanya gejala mulut berjamur dan bitnik-bintik merah pada kulit awal Tahun 2020 dan SU tertular pada Tahun 2019. Perasaan pertama yang dialami ODHApun beragam seperti kecewa, depresi dan pengen bunuh diri.

\section{Sikap tidak menghindar (non- avoidance)}

Sikap tidak menghindarnya orang dengan HIV/AIDS terhadap kejadian lingkungan dan interaksi sosialnya. Sikap tidak menghindar yang dimaksud yaitu ketika ODHA terkadang malu akan kondisi yang dimilikinya, sehingga mereka menarik diri dari lingkungan sekitarnya yang tidak memperlakukan dirinya berbeda ataupun diskriminatif kepadanya. Pernyataan informan RA menunjukan informan RA lebih memilih menarik diri pada orang-orang yang tidak sefrekuensi dengannya. Orang-orang yang tidak menghargai perbedaan dalam dirinya dan mendiskriminasin informan RA sehingga informan RA merasa tidak nyaman. Pernyataan yang sama juga disampaikan informan ED menunjukan bahwa diirinya menarik diri dari lingkungan karna merasa tidak ada orang normal yang mau berteman 
dengan orang HIV/AIDS dan lebih memilih bermain handphone sendirian di kamar. Pernyataan yang sama juga disampaikan oleh informan SU yang menjaga jarak dan mengurangi intensitas karna kondisi fisiknya yang sudah mulai melemah. Pernyataan informan BL menunjukan bahwasannya ODHA masih menjaga jarak untuk tidak menularkan, tapi ODHA di balai sudah mulai terbuka dengan orang lain.

Pernyataan informan RA menunjukan bahwa informan RA menarik diri dari keluarga dalam hal ini nenek dan keluarga besarnya, sedangkan adik dan mama informan RA karna sudah buka status dengan mereka dan mereka menerima RA dengan baik. Pernyataan yang sama juga di sampaikan oleh informan ED menunjukan bahwa ED menarik diri dari beberapa keluarganya, karna ED sudah buka Status dengan keluarga, mama dan adek perempuan ED meneriama ED dengan baik akan tetapi tidak semua keluarga peduli dengan status dan kondisi ED saat ini dimana keluarga ayah ED masih tidak menerima ED dengan baik dan ED menarik diri dari keluarga ayahnya. Pernyataan informan SU bahwa SU menarik diri dari keluarga, karna hanya beberapa keluarga SU yang menerima SU. informan SU juga sudah buka Status dengan beberapa keluarga akan tetapi informan SU agak menjauh dengan kakak nomor dua dan keponakannya.

Sikap tidak menghindar (nonavoidence) juga memiliki persamaan, perbedaan dan jawaban ODHA yang berbeda-beda. Persamanan pada aspek sikap tidak menghindar (non-avoidence) dijelaskan bahwa sikap informan RA dan ED terhadap situasi yang tidak mengenakan bagi dirinya ditunjukan dengan lebih memilih untuk tidak memperdulikan situasi yang tidak mengenaakan baginya, sedangkan informan SU memilih untuk mengingat ajaran agama dan melaksanakan ibadah sholat. Persamaan lainnya terletak pada sikap ODHA yang menarik diri dengan kelurganya. Persamaan lainnya terletak pada pernyataan informan yang menjelaksan bahwa ODHA kondisi ODHA menjauhkan diri dari orang lain adalah ketika Lingkungan yang tidak menghargai dan toxic dengan diri mereka

Perbedaan pernyataaan yang disampaikan informan pada aspek sikap tidak menghindar (non-avoidence) dijelaksan bahwa informan RA menarik diri dari lingkungan ketika orang-orang tidak sefrekuensi dengannya. informan ED menjelaskan bahwa dirinya menarik diri dari lingkungannya karna merasa tidak ada orang normal yang mau berteman dengan orang HIV/AIDS sedangkan informan SU Lebih memilih untuk menjaga jarak dengan orang-orang disekitarnya. Menjaga jarak karna secara sadar dirinya sudah terpapar virus HIV. Perbadaan lainnya adalah alasan ODHA menjaukan diri dari keluarga dan lingkungan dari pernyataan informan RA adalah dikarenakan nenek informan RA yang menyuruh informan RA menikah sehingga informan RA belum open status dengan nenek RA. Pernyataan informan ED adalah tetangga ED yang melarang informan ED untuk memegang 
barang tokonya sedangkan pernyataan informan SU menunjukan bahwa keluarga seperti enggan untuk berdekatan dengan informan SU karna takut tertular dan juga teman-teman SU banyak yang mencibirnya karna perubahan fisik yang terjadi pada informan SU.

\section{Sikap tidak menghakimi (nonjudgment)}

Tidak menghakimi yaitu menilai pengalaman sebagai baik atau buruk, benar atau salah, tidak menilai dari kejadian yang dialami melainkan menjadikan bahan evaluasi untuk kehidupan mendatang. Tidak boleh menilai segala peristiwa yang terjadi dalam hidupnya selalu buruk maupun sebaliknya namun harus secara utuh dan objektif. Pernyataan informan RA menunjukan bahwa menilai situasi yang dia alami baik baik saja, dan selalu bersyukur karna sekarang masih bisa bekerja. Pernyataan yang sama juga disampaikan oleh informan ED dimana informan ED menilai yang terjadi sebagai pembelajaran. Berikut pernyataan dari informan ED menunjukan bahwa menilai situasi yang dialami sebagai pembelajaran dalam hidupnya dan berharap semoga dia bisa menjadi lebih dewasa dan ada niat untuk berkuliah dan menjadi guru kesenian. Pernyataan yang sama juga disampaikan oleh informan SU dimana informan SU sudah menerima bersabar dan selalau berdoa.

Pernyataan informan TI menyampaikan bahwsannya ODHA di balai saat ini sudah menerima dan sudah tau penularan, pencegahan dan menangani penyakit mereka. Pernyataan serupa juga di sampaikan oleh informan BL bahwsannya ODHA di balai saat ini sudah menerima dan sudah tau cara menangani penyakit mereka karna banyak edukasi yang telah disampaikan kepada mereka.

Pernyataan informan RA mengatakan bahwasannya peran dari orang lain sangat berpengaruh terhadap penilain kondisinya saat ini. Orang-orang yang berpanguruh dalam menilai situasi yang informan RA alami adalah salah satu anggota keluraga yaitu adik infoman RA, Pendamping di LSM Medan Plus, tementemen SMP dan E juga sebagai temen satu balai. Pernyatan yang sama juga disampaikan oleh informan ED menunjukan bahwa perlunya peran dari orang lain dalam menilai situasi yang dia alami inorman ED mengatakan bahwasannya orang-orang yang berpanguruh dalam menilai situasi yang dia alami adalah beberpa anggota Keluraga seperti mama dan adik perempuan dan empat orang temen-temen SD. Pernyataan informan SU menunjukan bahwasannya orang-orang yang berpanguruh dalam menilai situasi yang dia alami adalah Kakak sulungnya dimana kakak sulungnya selalu mengingatkan untuk minum obat tepat waktu dan tetap baik sama semua orang, dan tetap ingat sama Allah.

$$
\text { Sikap tidak menghakimi }
$$
(nonjudgement) juga memiliki persamaan, perbedaan dan jawaban ODHA yang berbeda-beda. Persamanan pada aspek sikap sikap tidak menghakimi (nonjudgement) dijelaskan bahwa pernyataan informan RA, SU dan ED dalam menilai situasi yang mereka adalahh 
baik baik saja, dan selalu bersyukur karna sekarang masih bisa bekerja, sebagai pembelajaran dalam hidupnya dan berharap semoga dia bisa menjadi lebih dewasa. Persamaan lainnya juga terlatak bahwasannya ODHA dapat meneriman pujian dan kritikan terhadap dirinya.

Perbedaan pernyataaan yang disampaikan informan pada aspek sikap tidak menghakimi (nonjudgement) dijelaksan bahwa informan RA mampu untuk menilai postif situasi yang dia alami dikarenakan pendamping di LSM Medan Plus, temen-temen SMP dan E juga sebagai temen satu balai yang mendukungnya. Informan ED juga menjelaskan bahwa Orang-orang yang berpanguruh dalam menilai situasi yang dia alami adalah beberpa anggota Keluraga seperti mama dan adik perempuan dan empat orang temen-temen SD dan informan SU menyatakan bahwa orang yang berpanguruh dalam menilai situasi yang dia alami adalah kakak sulungnya. .

\section{Toleransi (Tolerance) ODHA terhadap keadaan yang tidak diinginkan}

Toleransi ODHA terhadap keadaan yang tidak ia inginkan mencakup kestabilan emosi dan cara mengatasi masalah. Toleransi ini dapat diwujudkan sebagai kontrol emosi yang stabil saat menghadapi kondisi yang tidak diinginkan. Pernyataan Informan RA menunjukan ketika mengamalami situsi yang tidak dinginkan maka informan RA mencoba mengalihkan dengan membaca buku dan mencoba memotivasi diri sendirinya. Pernyataan serupa juga disampaikan oleh informan ED menunjukan bahwa informan ED pernah mengalami situasi yang tidak ia inginkan ketika temannya menyuruh informan ED untuk menggunakan sarung tangan, dan pada saat itu informan ED ketika mengamalami situsi yang tidak dinginkan maka informan ED mencoba untuk tidak menanggapi dan menganggap itu karna kurangnya pengetahuan mereka. Pernyataan informan SU menunjukan bahwa ketika mengalami situsi yang tidak dinginkan maka informan SU mencoba untuk sabar dan mengalah walaupun itu sesorang yang lebih tua dan dewasa darinya dan meyakini suatu saat dia pasti akan mengerti. Adapun pernyataanpernyataan yang disampaikan oleh pendamping sosial ODHA dan pekerja sosial dalam hal ini Informan TI dan Informan BL mengenai ODHA dapat mentolerir situasi yang tidak ia inginkan Pernyataan informan TI menyampaikan ODHA bisa mentolerir situasi yang tidak mereka inginkan walaupun kejadian itu tidak sesuai dengan harapan hal yang sama juga disampaikan informan BL dimana informan BL menyampaikan ODHA dapat mentolerir situasi yang tidak dia inginkan karna ODHA selalu memegang komitmen dalam dirinya.

Toleransi (tolerance) ODHA terhadap keadaan yang tidak ia inginkan juga memiliki persamaan, perbedaan dan jawaban ODHA yang berbeda-beda. Persamanan pada aspek toleransi (tolerance) ODHA terhadap keadaan yang tidak ia inginkan dijelaskan bahwa 
Informan RA, ED dan SU dapat mentolerir situasi yang tidak mereka inginkan dengan cara mencoba mengalihkan dengan membaca buku dan mencoba memotivasi diri sendiri, mencoba untuk tidak menanggapi dan menganggap itu karna kurangnya pengetahuan mereka dan untuk sabar dan mengalah.

Perbedaan pernyataaan yang disampaikan informan pada aspek toleransi (tolerance) ODHA terhadap keadaan yang tidak ia inginkan dijelaksan bahwa informan RA mengalami situasi tidak dihargai ketika perawat rumah sakit memandang informan RA dengan ekspresi yang jijik dan berkesan mengejek atau menghina serta membalas perkataan informan RA dengan konotasi menghina, orang-orang sekitar yang berada dirumah sakitpun seperti berkesan memandang orang yang kepoli VCT dengan terkesan menghina. Informan ED mengalami Situasi tidak dihargai ketika perawat membocorkan dirinya kepada orang lain dalam hal ini keluarga perawat sehingga anggota keluarga perawat tersebut membocorkan statu ODHA informan ED kepada masyarakat dan informan SU Situasi tidak dihargai ketika kakak nomor dua dan keponakan informan SU tidak mau memakan masakan yang SU buat karna merasa jijik dan takut tertular 5.Kesediaan (willingness) informan dalam melaksanakan aktivitas

Kesediaan ODHA dalam menggunakan pilihannya dalam melakukan aktivitas mencakup bersosialisasi, menggunakan pilihan untuk mau mengikuti aktivitas walaupun dalam kondisi statusnya sebagai orang dengan HIV/AIDS. Kesediaan ini bertujuan untuk ODHA menganggap dirinya memiliki kelebihan berupa keterampilan yang dapat dioptimalkan sehingga tidak menganggap dirinya berbeda dan mau ikut beraktivitas dengan orang - orang di sekitarnya. Pernyataan informan RA menunjukan bahwa dirinya bersedia mengikuti segala kegiatan yang ada dibalai selagi kegiatan itu cocok dengan informan RA, dan dirasa dapat menambah keterampilan dan wawasan informan RA, begitu juga dengan kegiatan di masyarakat informan RA bersedia untuk ikut serta sebagai bentuk untuk melawan stigma dari masyarakat. Pernyataan yang sama juga disampaikan oleh informan ED menunjukan bahwa dirinya bersedia mengikuti segala kegiatan yang ada dibalai begitu juga dengan kegiatan di masyarakat informan ED bersedia untuk ikut serta asalkan masnyarakat juga menunjukan sifat menghargai dan ramah kepada informan ED.

Pernyataan informan SU menunjukan bahwa dirinya bersedia mengikuti segala kegiatan yang ada dibalai begitu juga dengan kegiatan di masyarakat informan SU bersedia untuk ikut serta dengan mengikuti berbagai kegiatan seperti jalan-jalan- senam dan lain sebagainya asalkan kegiatan tersebut tidak terlalu membebani fisik dari informan SU Pernyataan informan TI menunjukan bahwasanyaa ODHA di balai mengikuti semua kegiatan yang ada di balaik karna kegiatan yang di berikan sesuai dengan keinginan mereka. Seperti ada ODHA 
yang mengikuti kegiatan salon, desain grafis dan juga belajar masak. Pernyataan informan TI ini menyampaikan bahwasannya sebelum ODHA masuk ke balai sudah terlebih dahulu ditanyan kepada mereka apa saja keterampilan yang ingin anda ikuti dan ODHA sendiri yang memilih untuk mengikuti kegiatan yang sesuai dengan minat dan bakat mereka. Pernyataan yang senada juga disampaikan oleh pekerja sosial balai dalam hal ini informan BL.

Kesediaan (willingness) ODHA dalam melaksanakan aktivitas juga memiliki persamaan, perbedaan dan jawaban ODHA yang berbeda-beda. Persamanan pada aspek kesediaan (willingness) ODHA dijelaskan bahwa ODHA bersedia untuk mengikuti seluruh kegiatan rehabilitasi balai dan kegiatan yang ada di masyarakat selagi kegiatan itu cocok, dan dirasa dapat menambah keterampilan dan wawasan. ODHApun juga bersedia untuk bersosialisasi dengan orang lain bila orang tersebut mau terbuka dengan mereka.

Perbedaan pernyataaan yang disampaikan informan pada aspek kesediaan (willingness) ODHA dalam melaksanakan aktivitas dijelaksan bahwa kegitana ODHA di balai berbeda-beda. Informan RA menjelaskan bahwa dirinya mengikuti kegitan kegiatan 3 kali seminggu dalam balai dan ikut dalam kegiatan fotografi dan masak. Informan ED mengikuti kegiatan membuat donat dan boba, mc, dan sabtu minggu bermain badminton sedangkan informan SU Mengikuti kegiatan seperti Kegiatan barbershop senin sampai hari jumat dan ikut belajar kuliner setiap hari sabtu di balai

\section{Harapan informan terkait penerimaan diri akibat terinveksi HIV/AIDS}

Harapan-harapan yang dimaksud dalam hal ini yaitu harapan ODHA terkait kondisinya akibat terifeksi HIV/AIDS, harapan ODHA terhadap perilaku orangorang di sekitar lingkungannya dan harapan ODHA terhadap pihak BRSODH Bahagia Medan

Pernyataan dari ke tiga informan yaitu informan RA, informan ED dan informan SU terkait dengan kondisi mereka akibat terinveksi HIV/AIDS menunjukan bahwa mereka berharap dirinya bisa menerima diri lagi, tidak seteres dan tidak memikirkan hal- hal yang tidak perlu tidak menularkan kepada orang lain lagi, dan berhenti pada dirinya sendiri. Selalu sehat berfikir, selalu minum obat, berharap bahwa orang-orang HIV diluar sana termasuk dirinya tidak takut untuk bercerita, tidak menghakimi dirinya sendiri dan tidak merasa dirinya adalah manusia berdosa dan juga semoga ada bantuan dana dari pemerintah untuk pemenuhan kebutuhan mereka. pegawai dan juga dia juga selalu rajin ikut pengarahan dari pekerja sosial di balai.

Pernyataan dari informan TI, BL dan SU menujukan bahwasannya ODHA dapat menerima dirinya dengan apa adanya, mampu berdamai dengan diri mereka tidak menggap HIV/AIDS adalah musuh bagi mereka, dapat berubah, tertatur minum obat, dapat memperbaiki hidup, tidak 
menyesali keadaan mereka berharap, ODHA dapat menerima dirinya dengan apa adanya, dapat memperbaiki hidup dan tidak menyesali keadaan sehingga ODHA dapat bangkit dan mampu membekali diri mereka tentang edukasi HIV/AIDS.

Pernyataan dari informan TI, BL dan SU menujukan bahwasannya informan SU berharap orang- orang di disekitarnya dapat belajar tentang apa itu HIV/AIDS dan tau cara penularannya bahwa penularan HIV/AIDS tidak segampang itu tidak akan tertular dengan berjabat tangan atau berpelukan. Informan SU berharap masyarakat mau merangkul ODHA diluar sana begitu juga dengan informan RA berharap orang- orang di disekitarnya dapat menerima dan mau berteman dengan orang-orang dengan HIV/AIDS, karna tidak semua ODHA itu jahat atau berkelakuan buruk. Seperti yang terjadi kepada ibu-ibu rumah tangga yang tertular dari suaminya tanpa ibu rumah tangga berbuat jahat atau nakal kepada orang lain.

Pernyataan informan TI dan Informan BL menunjukan bahwa berharap orang- orang di disekitar ODHA bisa lebih mengetahui informasi dan edukasi tentang HIV/AIDS agara tidak mendiskriminasi dan menstigma ODHA, adanya peran dari keluarga, tetangga dan massyarakt terkait dengan penerimaan diri ODHA karna meraka adalah support system bagi ODHA itu sendiri

\section{PEMBAHASAN}

Pembahasan hasil penelitian yang terdiri dari analisis hasil penelitian, analisis masalah, analisis kebutuhan dan identifikasi sistem sumber.

\section{Perasaan ketidakterikatan (nonattachment)}

Williams \& Lynn dalam Bernard (2013) seseorang yang telah menerima dirinya akan tidak memiliki ketidakterikatan (nonattachment) yaitu menerima bahwa pengalaman yang telah berlalu, membiarkan pengalaman datang dan pergi lebih baik daripada upaya untuk mengendalikan atau mempertahankan pengalaman tersebut disekitarnya menggambarkan bahwa tidak menyalahkan diri, menerima kondisi atau kejadian yang telah berlalu, dan menerima motivasi dari lingkungan.

ODHA tidak terlalu terikat atas kejadian yang mereka alami tapi masih memerlukan penguatan. Kenyataan atau kejadian yang merubah dirinya ODHA merupakan hal yang berat seperti menimbulkan berbagai permasalah dan membutuhkan waktu untuk beradaptasi dengan kondisi yang baru sehingga perasaan ODHA pun ketika mengingat penyebab dirinya menjadi orang dengan HIV/AIDS merasakan ada rasa takut, Kecewa, sedih dan mau bunuh diri jika mengingat hal yang menyebabkan mereka menjadi seorang ODHA sehingga mereka harus selalu di berikan penguatan baik dalm bentuk, edukasi, obat, pendampingan dan ada seseorang yang mau mendengarkan cerita mereka. ODHA mulai sedikit demi sedikit menerima dan menyadari perbuatannya sebagai pembelajaran dalam hidupnya. ODHApun tidak mengetahui siapa yang menularkan 
HIV/AIDS pada mereka. Informaninforman diatas memiliki perilaku beresiko yaitu sering melakukan hubungan seksual sesama jenis dan mengetahui dirinya teridentifikasi HIV/AIDS setalah mengalami gejala seperti demam tinggi, vertigo, diare, badan terasa lelah dan pegal-pegal, lidah berjamur, alergi dan gatal-gatal.

Motivasi dari lingkunganpun sangat dibutuhkan Peran orang terdekat menjadi salah satu hal yang menyebabkan ODHA tidak terikat dengan masa lalunya orangorang tedekat tersebut bisa memberikan dukungan dan dan motivasi kepada ODHA dan mampu melewati masa sulit dalam hidupnya terutama peran keluarga, teman sebaya dan pendamping ODHA bisa menjadi berubahnya perlaku dan pola pikir ODHA menjadi lebih positif. Adanya dukungan teman sebaya, adanya konseling dan edukasi dari balai dan balai mendorong mereka untuk buka status dengan keluarga mereka. ODHA setelah berada di balai diberi penyadaran dukungan atau konseling dan informasi yang benar maka ODHA di balai mulai bangkit untuk tidak menyalahkan dirinya.

\section{Sikap tidak menghindar (non- avoidancE)}

Williams \& Lynn dalam Bernard (2013) seseorang yang telah menerima dirinya dengan baik akan tidak menghindar (non-avoidance) yaitu menahan diri untuk tidak melarikan diri ketika tidak ada ancaman atau tidak menghindarnya orang dengan HIV/AIDS terhadap lingkungan dan interaksi sosialnya. Faktor dari lingkungan juga sangat mempengaruhi sikap ODHA seperti pendapat Hurlock (1976) yang mengemukakan faktor-faktor yang mempengaruhi penerimaan diri yaitu salah satunya lingkungan yang stabil, hal ini tentunya sesuai dengan hasil penelitian yang menggambarkan bahwa ODHA tidak melakukan penarikan diri dalam lingkungan yang aman.

ODHA lebih memilih untuk menghindar dan menjaga jarak dengan lingkungannya dan beberapa anggota keluarganya karna merasa bahwa tidak ada orang yang mau berteman dengan orang yang terkena virus HIV/AIDS. ODHA juga mengurangi intensitas untuk melakukan interaksi dikarenakan mereka merasa kondisi fisik mereka ada beberapa yang lemah dan berusaha untuk tidak menularkan kepada orang lain, ODHA di balai sudah buka status dengan keluarga hanya saja tanggapan dari keluarga berbeda-beda. Ada yang ada yang mensupport, ada yg tidak peduli, ada yang tidak mau nerima mereka bahkan menstigma dan mendiskriminasi ODHA. Pihak yang mempengaruhi sikab ODHA untuk menghindar dari orang lain adalah keluarga informan sendiri, teman dan juga tetangga yang terkadang tidak peduli, mendiskriminasi dan menstigma ODHA. Tidak semua keluarga mau menerima ODHA, hanya beberapa anggota keluarga saja yang mau menerima ODHA dengan baik kurangnya dukungan dari kerluarga menyebabkan banyak ODHA memilih untuk menjauhkan diri dari orang lain.
3.Sikap
tidak
menghakimi 
Williams and Lynn dalam Bernard (2013) menggambarkan tidak menghakimi (nonjudgment) yaitu penghentian secara sadar dari kategorisasi pengalaman sebagai baik atau buruk, benar atau salah, menggambarkan rangsangan daripada mengevaluasi rangsangan yaitu menilai pengalaman sebagai baik atau buruk, benar atau salah, menilai kejadian yang dialami menjadikan bahan evaluasi untuk kehidupan mendatang. Tidak menghakimi ini juga memandang keseluruhan secara objektif seperti teori yang di sampaikan oleh Agoes (2007) Sikap penerimaan realistis ditandai dengan kemampuan memandang segi kelemahan-kelemahan maupun kelebihan-kelebihan diri sendiri secara objektif.

Sikap tidak menghakimi yang dilakukan bahwa ODHA dalam menilai situasi yang dia alami adalah ODHA cenderung lebih menerima, pembelajaran dalam hidupnya berharap semoga dia bisa menjadi lebih dewasa lebih sabar, tetap rendah hati, tetap yakin dan untuk lingkungan mereka berharap untuk tidak saling membenci. Hal ini tidak terlepas dari edukasi dan informasi yang mereka terima serta peran pemdampingan dan komunitas tempat mereka belajar sehingga menganggap kondisi yang mereka alami baik-baik saja dan selalu bersyukur. Pihak yang terlibat dalam menilai situasi yang ODHA alami adalah terutama kelurga ODHA dimana peran dari keluarga sangat dibutuhkan oleh ODHA untuk menilai situasi yang dialami. Peran dari beberapa anggota keluarga membuat ODHA lebih berfikir positif dan tidak menilai hal yang terjadi dalam hidupnya adalah sesuatu yang buruk tetapi menjadi pihak yang mendorong ODHA untuk tetap melanjutkan hidup. Selain keluarga adapun pihak lain yang turut serta berperan ODHA dalam menilai situasi yang dia alami adalah, teman-teman sebaya dan pendamping di komunitas ODHA. ODHA dapat menerima dan sudah terbiasa dengan segala bentuk pujian dan juga menerima berbagai kritikan asalkan kritikan itu disampaikan dengan tepat dan benar mereka tidak marah jika kritikan itu bermanfaat dan bersifat membangun untuk mereka.

4. Toleransi (Tolerance) ODHA terhadap keadaan yang tidak ia inginkan

Williams \& Lynn dalam Bernard (2013) menggambarkan mengenai penerimaan diri yang baik memiliki toleransi (tolerance) dapat tetap hadir bahkan ketika rangsangan membuat frustrasi atau tidak diinginkan. Garmer (2009) juga menjelaskan bahwa Toleransi berarti menanggung rasa sakit emosional yang dirasakan, tetapi individu tetap melawannya dan berharap perasaan tersebut akan segera hilang dengan sendirinya.

Toleransi ODHA terhadap situasi yang tidak ia inginkan adalah dapat mengendalikan emosinya dan mencoba mengalihkannya dengan mengganggap bahwa itu terjadi karna kurangnya edukasi dan informasi dan berfikir kenapa ODHA harus menyerah sama hidup atau keadaan yang ODHA alami sekarang. Bentuk diskriminasi yang dialami oleh ODHA 
berbagai macam seperti perawat rumah sakit memandang ODHA dengan ekspresi yang jijik dan berkesan mengejek atau menghina, sebagian anggota keluarga juga sering melakukan diskriminasi kepada ODHA dengan takut memakan masakan buatan ODHA karna merasa dapat menularkan HIV/AIDS. Solusi ODHA menahan diri untuk tidak menyalahkan diri sendiri adalah tetap berfikir positif, menerima, mengiklaskan apa yang sudah terjadi, dan mengalihkan perasaanperasaan setres kepada kegiatan yang positif seperti rekreasi, olahraga dan beribadah.

Pihak Yang berpengaruh Terhadap Toleransi ODHA adalah teman-teman sebaya ODHA dan sebagain anggota keluarga ODHA. Teman-teman sebaya inilah yang bisa menenangkan perasaan ODHA karna bisa menjadi tempat mereka curhat, dan tempat mereka untuk saling tolong menolong. Keluarga juga menjadi pihak yang berperan terhadap toleransi mereka dimana keluarga inilah yang selalu menyemangati, memberi dukungan dan mengingatkan ODHA.

\section{Kesediaan (willingness) informan dalam melaksanakan aktivitas}

Williams \& Lynn dalam Bernard (2013) menggambarkan penerimaan diri sebagai kesediaan (willingness) menggunakan pilihan untuk memiliki pengalaman bersosialisasi dan melakukan aktivitas.

Kesediaan ODHA dalam melakukan aktivitas dijelaskan telah dapat bersosialisasi dengan cukup baik, ODHA bersedia mengikuti berbagai kegiatan di balai dan masyarakat,jika masyarakat ramah kepada mereka Adapun berbagai kegiatan yang diikuti oleh ODHA selama di balai beraneka ragam seperti kegiatan on, desain grafis, fotografer, kuliner, mc, badminton dan lain-lain dan mereke juga mengikuti kegiatan berupa terapi psikososial, terapi fisik, moorning meeting dan terapi kehidupan dan mereka semua rutin dan rajin mengikuti kegiatan tersebut Sedangkan rutinitas kegiatan dimasyarakat masih belum ada dikarenakan ODHA masih berfokus untuk untu menjalani masa rehabilitasi di BRSODH Bahagia Medan berbagai pihak sangat di butuhkan untuk mempengaruhi kesediaan ODHA dalam melakukan kegaiatan di balai. Pihak-pihak seperti pendamping sosial ODHA, Psikolog, pekerja sosial sangat berarti untuk memberi dukungan, semangat dan edukasi kepada ODHA dalam kesediaan mereka mengikuti kegiatan tersebut.

\section{Harapan penerimaan diri akibat terinveksi HIV/AIDS}

ODHA memilki harapan terkait kondisinya akibat terifeksi HIV/AIDS, harapan ODHA terhadap perilaku orangorang di sekitar lingkungannya dan harapan ODHA terhadap pihak BRSODH Bahagia Medan. Hasil penelitian menujukan Harapan ODHA Terhadap Kondisinya Akibat Terinfeksi HIV/AIDS adalah tidak seteres dan tidak memikirkan hal- hal yang tidak perlu tidak menularkan kepada orang lain lagi, dan berhenti pada dirinya sendiri. ODHA juga berharap orang-orang disekitarnya dapat belajar tentang apa itu HIV/AIDS dan tau cara penularannya serta adanya peran dari 
keluarga, tetangga dan masyarakat terkait dengan penerimaan diri ODHA karna meraka adalah support sistem bagi ODHA itu sendiri. ODHA juga berharap pihak balai pelayanan di balai semakin berkelanjutan di berikan kepada penerima manfaat agar banyak ODHA bisa terus mengembangkan keterampilannya di balai dan agar balai dapat lebih banyak menerima penerima manfaat kembali serta meningkatkan fasilitas balai yang lebih baik.

Masih terdapat berbagai masalah dan kekurangan dalam Penerimaan Diri Orang Dengan HIV/AIDS Di Balai Rehabilitasi Sosial ODH "Bahagia" Medan Provinsi Sumatera Utara. Masalah-masalah tersebut adalah

1. Pada aspek sikap tidak mengindar ODHA mengalami masalah yaitu sikap menghindar dari beberapa anggota keluarganya dikarenakan setelah buka status tanggapan dari keluarga berbedabeda, ada yang mensupport, ada yg tidak peduli, ada yang tidak mau nerima mereka bahkan menstigma dan mendiskriminasi ODHA

2. Permasalah yang timbul adalah adanya sikap menghindar dan menjaga jarak dari lingkungan masyarakat karna ODHA merasa bahwa tidak ada orang yang mau berteman dengan orang yang terkena virus HIV/AIDS. Anggapan bahwa dirinya adalah seorang ODHA membuatnya malu dan menganggap bahwa apa yang terjadi pada dirinya

Kebutuhan yang diperlukan terkait penerimaan diri Orang Dengan adalah suatu yang harus ditutupi dari lingkungan luar sehingga kebanyakan dari ODHA akan menarik diri dari lingkungan.

3. Pada aspek perasaan ketidakterikatan diketahui bahwa ODHA tidak terlalu terikat dengan masa lalunya dan berusaha untuk tidak menyalahkan dirinya sendiri akan tetapi ODHA masih perlu diberi penguatan karna ketika mengingat kejadian dimasa lampau terutama kejadian yang membuat mereka menjadi berstatus orang dengan HIV/AIDS karna adanya kebingungan mengalami penularan dari siapa sehingga menyebabkan Adanya perasaan kecewa, sedih dan takut dalam diri ODHA, tidakterikatan menjadi aspek yang sulit dilakukan karena menyebabkan trauma kepada beberapa orang sehingga membutuhkan penguatan dari berbagai pihak dan membutuhkan waktu untuk melakukan penyesuaian di dalam hidupnya.

4. Permasalahan lainnya adalah sebagian anggota kelurarga ODHA juga sering melakukan diskriminasi kepada ODHA dengan takut memakan masakan buatan ODHA karna merasa dapat menularkan HIV/AIDS. Kurangnya edukasi dan informasi menjadi alasan beberapa keluarga menjauhI ODHA. Keluarga sangat dibutuhkan oleh ODHA sebagai support sistem dan pemberi dukugan dan motivasi bagi mereka

HIV/AIDS, hal tersebut dapat dirumuskan melalui kebutuhan-kebutuhan yang 
diperlukan oleh ODHA. Kebutuhankebutuhan tersebut antara lain:

1. Peningkatan Konseling Individu Peningkatan konseling sangat dibutuhkan oleh ODHA agar ODHA tetap bisa mempertahankan pandangan positif terhadap dirinya sendiri. Pemberian bantuan dan dukungan sangat dibutuhkan oleh ODHA dengan tujuan untuk meningkatkan pernerimaan dirinya sebagai orang dengan HIV/AIDS agar bisa berdamai dengan penyakitnya, meningkatkan kemampuan ODHA dalam hubungan interpersonal secara lebih baik atau dengan kata lain meningkatkan kemampuan penyesuaian diri ODHA dengan lingkungan sosialnya, Meningkatkan kemampuan ODHA untuk mengambil keputusan secara bertanggungjawab., membimbing dan meningkatkan keterampilan ODHA dalam menghadapi masalah, memberikan motivasi untuk terus meningkatkan potensi dan keterampilan untuk menunjang kehidupannya,

mengembangkan kemampuan dalam proses pengambilan keputusan dan membantu ODHA dalam perubahan tingkah laku.

2. Edukasi kepada keluarga ODHA Keluarga sangat dibutuhkan oleh ODHA sebagai support sistem dan pemberi dukugan dan motivasi bagi mereka. Peningkatan penerimaan ODHA juga di perngaruhi oleh keluarga. Jika keluarga tidak peduli kemudian mendiskirminasi dan menstigama ODHA maka akan berpengaruh pada ODHA untuk menarik diri dan menghindar dari keluargnya sendiri. Pemberian tentang edukasi dan informasi mengenai HIV/AIDS sangat dibutuhkan oleh keluarga agar bisa mengetahui perannya sebagai support sistem bagi ODHA itu sendiri.

3. Dukungan Masyarakat Terhadap ODHA

Dukungan dari orang-orang yang terdekat atau significant others untuk ODHA memberikan pengaruh yang besar dalam perkembangan psikis, sosial, maupun emosi bagi ODHA. Lingkungan juga turut membentuk sikap penerimaan diri suatu individu dalam menerima kondisi dirinya dari segi kelebihan maupun kelemahannya. Dukungan dari lingkungan yang dibutuhkan oleh ODHA dapat berupa sikap seperti tidak membeda-bedakan ODHA, mau berinterksi dengan ODHA, tidak menstigma dan mendiskriminasi ODHA, bersedia menerima apa adanya, memberikan peluang untuk mendapatkan sesuatu yang menjadi haknya dan mendukung potensi-potensinya.

Sumber dari permasalahan dan kebutuhan diatas adalah sebagai berikut:

1. Sistem Sumber Informal

Sistem sumber informal merupakan sistem sumber yang dapat diberikan melalui dukungan emosional, kasih sayang, nasihat, informasi, dan pelayanan yang bersifat konkret. Sistem sumber informal yang dapat membantu ODHA di BRSODHA Bahagia Medan adalah pendamping sosial, teman-temannya yang ada di Balai Rehabilitasi Sosial ODH "Bahagia" Medan serta keluarga ODHA 
itu sendiri. Pendamping sosial ODHA dan teman sebaya ODHA dapat menjadi tempat sharing bagi ODHA dan bisa memberi saran dalam menyelesaikan masalah begitu juga dengan Keluarga selaku pemberi memberi motivasi dan dukungan sosial kepada ODHA Sistem Sumber Formal Sistem sumber formal merupakan sistem sumber yang berdasarkan keanggotaan dalam organisasi atau lembaga dengan tujuan untuk meningkatkan kapasitas seseorang. Sistem sumber informal yang dapat dimanfaatkan oleh ODHA di BRSODHA Bahagia Medan adalah Kepala BRSODHA Bahagia Medan, Pekerja Sosial BRSODHA Bahagia Medan, Psikolog BRSODHA Bahagia Medan, dan pengurus BRSODHA Bahagia Medan.

\section{Sistem Sumber Kemasyarakatan}

Sistem sumber kemasyarakatan yaitu lembaga-lembaga yang didirikan oleh pemerintah maupun swasta yang memberikan pelayanan kepada semua orang. Pihak yang dapat memberikan pelayanan untuk membantu ODHA yaitu rumah sakit, puskesmas, dinas sosial, tokoh-tokoh masyarakat seperti ketua RT/RW dan kader-kader yang berada di sekitar tempat tinggal ODHA.

\section{KESIMPULAN}

Perasaan

Ketidakterikatan (nonattachment) menunjukan bahwa ODHA tidak terlalu terikat atas kejadian yang mereka alami ODHA mulai sedikit demi sedikit menerima dan menyadari perbuatannya sebagai pembelajaran dalam. Sikap tidak Menghindar (non-avoidance) menunjukan ODHA lebih memilih untuk menghindar dan menjaga jarak dengan lingkungannya dan beberapa anggota keluarganya karna merasa bahwa tidak ada orang yang mau berteman dengan orang yang terkena virus HIV/AIDS.

Sikap Tidak Menghakimi (nonjudgment menunjukan dalam menilai situasi yang dia alami ODHA cenderung lebih menerima, pembelajaran dalam hidupnya berharap semoga dia bisa menjadi lebih dewasa lebih sabar, tetap rendah hati, tetap yakin dan untuk lingkungan mereka berharap untuk tidak saling membenci, hal ini tidak terlepas dari edukasi dan informasi yang mereka terima serta peran pendampingan dan komunitas tempat mereka belajar sehingga menganggap kondisi yang mereka alami baik-baik saja dan selalu bersyukur. Pihak yang terlibat dalam menilai situasi yang ODHA alami adalah terutama kelurga ODHA dimana peran dari keluarga sangat dibutuhkan oleh ODHA untuk menilai situasi yang dialami.

Toleransi ODHA terhadap situasi yang tidak ia inginkan menunjukan bahwa ODHA dapat mengendalikan emosinya dan mencoba mengalihkannya dengan mengganggap bahwa itu terjadi karna kurangnya edukasi dan informasi dan berfikir kenapa ODHA harus menyerah sama hidup atau keadaan yang ODHA alami sekarang. Kesediaan ODHA dalam melakukan aktivitas dijelaskan telah dapat bersosialisasi dengan cukup baik, ODHA bersedia mengikuti berbagai kegiatan di balai dan masyarakat, jika masyarakat ramah kepada mereka. 
Harapan ODHA terhadap kondisinya akibat terinfeksi HIV/AIDS adalah tidak seteres dan tidak memikirkan hal- hal yang tidak perlu tidak menularkan kepada orang lain lagi, dan berhenti pada dirinya sendiri. ODHA juga berharap orang-orang disekitarnya dapat belajar tentang apa itu HIV/AIDS dan tau cara penularannya. ODHA juga berharap pihak balai pelayanan di balai semakin berkelanjutan di berikan kepada penerima manfaat agar banyak ODHA bisa terus mengembangkan keterampilannya.

\section{DAFTAR PUSTAKA}

Adi Fahrudin. (2012). Pengantar Kesejahteraan Sosial. Bandung: Refika Aditama

Agoes Dariyo. (2007). Psikologi Perkembangan Anak Tiga Tahun Pertama. Jakarta: Refika Aditama.

Bernard, Michael E. (2013). The Strength of Self-Acceptance Theory, Practice and Research.Springer: New York. Brooks, D. M. (2010). HIV-related case management. Handbook of HIV and social work. Hal 77-88.

BRSODH Bahagia Medan, Profil BRSOD Bahagia Medan Diunduh pada tanggal 24 Agustus 2020 dari https://bahagia.kemsos.go.id/tentangkami/

Chaplin, J.P. (2012). Kamus Lengkap Psikologi. Jakrata: Pt. Raja Grafindo Persada

Damanik, Juda. (2008). Pekerjaan sosial. Jakarta: Pusat Perbukuan Departemen Pendidikan Nasional

Departemen Kesehatan RI dan UNAIDS. (2002). Sidang Kabinet Sesi Khusus HIV I AIDS Maret 2003. Penanggulangan HIVIAIDS Di Indonesia: Respon Saat Ini- Menangkal Ancaman Bencana Nasional AIDS
Mendatang. Jakarta: Departemen Kesehatan.

Direktorat P2P Kemenkes RI. (2020). Laporan Perkembangan Hiv Aids \& Penyakit Menular Seksual (PIMS) Triwulan IV Tahun 2020. Jakarta: Kementrian Kesehatan RI

Germer, Christhoper K. (2009). The Mindful Path To Self-Compassion. United State Of America: The Gulford Press

Garvin. (1999). Tentang Group Work. Bandung: Poltekesos Bandung

Hurlock, Elizabeth B. (2007). Psikologi Perkembangan Suatu Pendekatan Sepanjang Rentang Kehidupan Edisi Kelima. Jakarta: PT Erlangga

I Komang Gunung, dkk. (2003). Buku Pengangan Konselor HIV/AIDS. Denpasar: Yayasan Burnet Indonesia Infodatin. (2020). Situasi Penyakit HIV Di Indosensia. Jakarta: Pusdatin Kementrian Kesehatan RI

Moch Zaenal Hakim (2014). Intervensi Pekerjaan Sosial dengan bagi ODHA (1): Proses Pertolongan dan Peranperan Pekerja Sosial, serta prinsipprinsip Bekerja di Lapangan. Dalam Lina Favourita (ed.) Praktik Pekerjaan Sosial dengan HIV/AIDS. Bandung: Pusat Kajian dan Layanan HIV/AIDS STKS Bandung.

Moleong, Lexy J. (2017). Metodelogi Penelitian Kualitatif. Bandung: PT. Remaja Rosdakarya

Nurhayati, Siti. (2018). Penerimaan Diri Pada Remaja Yang Mengalami HIV/AIDS. Jurnal Buletin Kesehatan. Vol. 2 No. 1

Nurviana, E.V. (2006). Penerimaan Diri Pada Penderita Leukimiai. Jurnal Psikologi Proyeksi. Vol. 7, No. 1.

Peraturan Menteri Sosial Nomor 08 Tahun 2012 tentang Pedoman Pendataan dan Pengelolaan Data Penyandang Masalah 
Kesejahteraan Sosial dan Potensi dan Sumber Kesejahteraan Sosial

Prihadi, S. F. (2004). Assessment Centre: Identifikasi, pengukuran dan Pengembangan Kompetensi. Jakarta:

Gramedia Pustaka Utama

Richardson, Diane. (2002). Perempuan dan AIDS. Yogyakarta: Medpress

Penelitian Kuantitatif, Kuaitatif, dan $R \& D$. Bandung: CV. Bandung.

UNAIDS. (2016). Global AIDS Update 2016. Geneva: Joint United Nations Programme on HIV/AIDS

Zastrow, Charles. (2000). Introduction to Social Work and Social Welfare. United States: Brooks Cole.

\section{Internet}

BRSODH Bahagia Medan, Profil BRSOD Bahagia Medan.Diunduh pada Tanggal 24 Agustus 2020 dari https://bahagia.kemsos.go.id/tentangkami/ 